
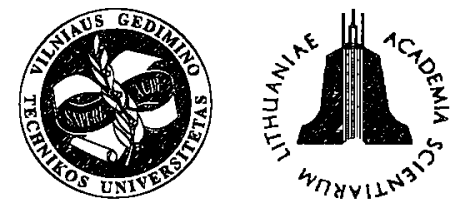

ISSN 1648-4142 TRANSPORT

http:/www.vtu.lt/english/editions

\title{
THE IMPLEMENTATION OF NEW CARRIAGE TECHNOLOGIES IN THE LITHUANIAN RAILWAY TRANSPORT AND ESTABLISHMENT OF THE PROSPECTIVE MARKETS FOR RAILWAY AND ROAD TRANSPORT*
}

\author{
Jonas Butkevičius \\ Dept of Transport Management, Vilnius Gediminas Technical University, \\ Plytinès g. 27, LT-2016, Vilnius, Lithuania.E-mail: vladas@ti.vtu.lt
}

Received 200302 05; accepted 20030630

\begin{abstract}
This article provides the analysis of the possibilities to instal new technologies in the Lithuanian railways the building of a high speed railway line I in Kreta corridor. It is advisable to project this line as a mixed one, i.e. intended for both passenger and goods traffic.

The research carried out by the author has shown that light transport dominates in passenger transportation among four cities of Lithuania Vilnius, Kaunas, Klaipeda and Šiauliai, which transports even $81,3 \%$ of direct passengers. Buses carry $14,9 \%$ and only $3,8 \%$ of passengers are carried by railway transport. Therefore the main problem public transport is facing is to "get the passengers back" from light transport means, i.e. cars.

The prospective railway and road transport markets in local, intercity and international passengers' transportations are also established in this work.
\end{abstract}

Keywords: public transport, transportations markets, transportation technology, super-fast railway.

\section{Introduction}

Railway transport, competing with road and air transport in the transportation market, was also improving - the transportation speed, its comfortability and safety were increasing. Thus a technologically new kind of railway evolved - a high speed railway intended for passengers' transportation. In the beginning trains traveled at $160 \mathrm{~km} / \mathrm{h}$ speed, however, such speed was too slow in a competitive struggle with other kinds of transport, especially with air transport. Thus, a necessity to increase the speed emerged. Nowadays high speed line trains travel at $260 \mathrm{~km} / \mathrm{h}$ and even at a greater speed.

All together there are $5,000 \mathrm{~km}$ of new high speed railway lines in the world and more than $11,000 \mathrm{~km}$ of the railway which has been reconstructed into high speed lines. In the period between 1964-2001 the high speed railways transported more than 6 billion of passengers. More than 1,2 thousand of high speed trains travel all over the world twenty-four hours every day.

The following foreign scientists have studied the development of problems of a high speed railway: V. Brännlung, P. Lindberg, O. Nou, A. Nilson, M. Knuton, I. Kiseliov, E. Sotnikov, V. Suchodojev [1-6] as well and Lithuanian ones: K. Sakalauskas and R. Rezgaitis [7].

* Discussion of results of programme "Transport: technologies, economic, environment, health"
2. The Implementation of New transportation Technologies in the Lithuanian Railway Transport

The author put forward the idea of the implementation of high speed railways in Lithuania in 1988. Due to the fact that two Kreta corridors extend all over our country (I - north - south and IX - west - east) there is a possibility for the Lithuanian railways to join the European transport network of high speed railways. One of the most important ways of joining it is the building of the European track for a high speed railway line in I Kreta corridor.

The research carried out by the author [8-10] shows that it is possible to build such high speed railways in Lithuania. That would extend I Kreta corridor over Poland, Latvia, Estonia and Russia. In 1997 a high speed railway line to Berlin was built. Its further track should be built from Berlin via Warsaw, Šeštokai, Kaunas or Vilnius, Šiauliai, Riga, Tallinn with a branch to St. Petersburg. Therefore this project has to be conducted by all Baltic states and Poland as well. Russia should build the branch to St. Petersburg. The length of the international I Kreta corridor Warsaw - Šeštokai - Kaunas - Riga - Tallinn in Lithuania is $332,7 \mathrm{~km}$ (it consists of $191,9 \mathrm{~km}$ of singleway road districts and $140,8 \mathrm{~km}$ of two-way road sections).

The author suggests that the railway extending along I Kreta corridor across Lithuania should not be used only for passengers' transportation. The density of population 
in Lithuania is much lower than in Western Europe. Besides Lithuania itself is not big, that is why its people do not have a great need to travel long distances. As a result there will be no considerable flows of passengers that would ensure the pay-off of the funds spent on building that line. Thus, we should follow Germany's example, where the recoupment of the part of new lines is guaranteed only, when cargo trains of a certain category are exploited, which can travel up to $160 \mathrm{~km} / \mathrm{h}$. An increase of speed of cargo trains lets them to take a firm position in the cargo carriage market. Bearing in mind the example of foreign countries, the author suggests that a mixed type of high speed railway line in I Kreta corridor should be built. intended for both passengers and goods traffic. Cargo trains should be included into integrated scheme of passenger transportation carried out by high speed trains identifying the so-called "windows" in the traffic schedule. Moreover the author proposes the following ideas $[9,11]$ :

- As Lithuania will not be able to finance the implementation of such a project, it is necessary to attract foreign capital as well as private. The basic source of financing is EU structural funds. One of the possible variants to finance the remaining part of the project is the granting of concessions to foreign partners.

- The carried out analysis has demonstrated that it is expedient in the analysed high speed railway line to use trains with lurching carriages according to the example of Swedish X2000 and Italian pendolino high speed trains.

- The construction of the line for the traffic of "lurching hull trains" would enable us to save some funds for building.

Having applied the formalized models of road transport and having compared railway and air transport it was ascertained that:

- while travelling up to $300 \mathrm{~km}$, road transport dominates,

- if the distance is bigger than $1400 \mathrm{~km}$, air transport dominates,

- high speed railways prevail when distances fluctuate from 900 to $1400 \mathrm{~km}$.

Despite of a considerably high cost of the construction of the above-mentioned high speed railway track route, Lithuania as well as other Baltic states - Latvia, Estonia as well as adjacent Poland cannot remain aside white developing the global transport system. The construction of the high speed railway line in Lithuania will create favourable conditions for the country's integration into the European transport network as well as encourage the development of the entire country's economy. Any delay in the implementation of technologies, especially in transport, will lead to great economic and social losses.

The introduction of high speed railway lines in France has proved to be very profitable for passenger transportations. The French railways are now collecting half of their income from passengers' transportations. That demonstrates how economical high speed railways are.

\section{The Research into the Distribution of Passenger Transportations in accordance with Various Means of Transport among Lithuania's Main Cities}

The distribution of the intercity passengers' flows carried by various means of transport has not been investigated in Lithuania yet, however, this distribution is important identifying the passenger transportation markets. This year in May the author carried out the research into the passengers' flows among Lithuania's four biggest cities - Vilnius, Kaunas, Klaipeda and Šiauliai. Daily direct flows from town to town by various means - bus (including microbuses), train and car were examined. The research findings are presented in Table.

The direct passengers flows among Vilnius, Kaunas, Klaipeda and Šiauliai are presented in Table

The conducted research into passenger flows has revealed a number of interesting facts. First of all, fifteen years ago or more the main intercity passenger flows were carried by rail or bus where as nowadays as much as four-fifths, i.e. $81,3 \%$ of direct passenger flows between theses cities are transported by car. Buses transport only $14,9 \%$ of passengers and trains carry only a very small part, i.e. 3,8 \% of direct passengers from one city to another. For example, over $76,4 \%$ of passengers go by car from Vilnius to Kaunas and in the opposite direction, by analogy $80,6 \%$ of passengers travel between Vilnius and Šiauliai, 84,6\% - between Vilnius and Klaipeda, $91,00 \%$ of passengers - between Kaunas and Šiauliai, $85,8 \%$ of passengers - between Kaunas and Klaipeda and $87,1 \%$ of passengers - between Šiauliai and Klaipèda.

Another important fact is that relatively small direct flows of passengers among these cities are transported by train - only 3,8\% of passengers.

One more interesting fact is that the daily flow of passengers going by car from Kaunas to Vilnius is twice as big as that the from Vilnius to Kaunas -3780 and 1525 correspondingly. It can be explained by the fact that the capital attracts much bigger flows of people (Fig 1).

Another significant fact is relatively small occupancy of a car. It varies from 1,5 to 1,8 passengers in some directions (including the driver). As a result going by car becomes more expensive than going by train or bus. However, a man still chooses this means of transport. What are the factors determining such a choice?

Firstly it should be mentioned here that public transport has lost its attractiveness due to its slow communication speed and lack of comfort although in recent years comfort has gradually been improving in public transport. 
Average passengers flows and their percent distribution in accordance with their transportation by train bus or car every day among Vilnius, Kaunas, Klaipeda and Šiauliai (directly from one city so another)

\begin{tabular}{|c|c|c|c|c|c|c|c|c|}
\hline \multirow[t]{2}{*}{ Direction } & \multicolumn{2}{|c|}{ Total } & \multicolumn{2}{|c|}{ By train } & \multicolumn{2}{|c|}{ By bus } & \multicolumn{2}{|c|}{ By car } \\
\hline & $\begin{array}{l}\text { the } \\
\text { number of } \\
\text { passengers }\end{array}$ & $\%$ & $\begin{array}{c}\text { the number } \\
\text { of } \\
\text { passengers }\end{array}$ & $\%$ & $\begin{array}{c}\text { the number } \\
\text { of } \\
\text { passengers }\end{array}$ & $\%$ & $\begin{array}{c}\text { the number } \\
\text { of } \\
\text { passengers }\end{array}$ & $\%$ \\
\hline Vilnius - Kaunas & 2401 & 100 & 159 & 6.6 & 717 & 29,9 & 1525 & 63,5 \\
\hline Kaunas - Vilnius & 4539 & 100 & 164 & 3.6 & 595 & 13,1 & 3780 & 83,3 \\
\hline $\begin{array}{l}\text { Totally between Vilnius } \\
\text { and Kaunas }\end{array}$ & 6940 & 100 & 323 & 4.7 & 1312 & 18,9 & 5305 & 76,4 \\
\hline Vilnius - Šiauliai & 869 & 100 & 66 & 7,6 & 102 & 11,7 & 701 & 80,7 \\
\hline Šiauliai - Vilnius & 641 & 100 & 49 & 7,6 & 76 & 11,9 & 516 & 80,5 \\
\hline $\begin{array}{l}\text { Totally between Vilnius } \\
\text { and Šiauliai }\end{array}$ & 1510 & 100 & 115 & 7,6 & 178 & 11,8 & 1217 & 80,6 \\
\hline Vilnius - Klaipèda & 1297 & 100 & 23 & 1,8 & 148 & 11,4 & 1126 & 86,8 \\
\hline Klaipèda - Vilnius & 760 & 100 & 15 & 1,9 & 132 & 17,4 & 613 & 80,7 \\
\hline $\begin{array}{l}\text { Totally between Vilnius } \\
\text { and Klaipeda }\end{array}$ & 2057 & 100 & 38 & 1,8 & 280 & 13,6 & 1739 & 84,6 \\
\hline Kaunas - Šiauliai & 848 & 100 & 0 & 0 & 73 & 8,6 & 775 & 91,4 \\
\hline Šiauliai - Kaunas & 830 & 100 & 0 & 0 & 78 & 9,4 & 752 & 90,6 \\
\hline $\begin{array}{l}\text { Totally between Kaunas } \\
\text { and Siauliai }\end{array}$ & 1678 & 100 & 0 & 0 & 151 & 9,0 & 1527 & 91,0 \\
\hline Kaunas - Klaipeda & 739 & 100 & 0 & 0 & 99 & 13,4 & 640 & 86,6 \\
\hline Klaipèda - Kaunas & 668 & 100 & 2 & 0,3 & 100 & 15,0 & 566 & 84,7 \\
\hline $\begin{array}{l}\text { Totally between Kaunas } \\
\text { and Klaipèda }\end{array}$ & 1407 & 100 & 2 & 0,1 & 199 & 14,1 & 1206 & 85,8 \\
\hline Šiauliai - Klaipèda & 503 & 100 & 30 & 6,0 & 11 & 2,2 & 462 & 91,8 \\
\hline Klaipėda - Šiauliai & 458 & 100 & 44 & 9,6 & 39 & 8,5 & 375 & 81,9 \\
\hline $\begin{array}{l}\text { Totally between Šiauliai } \\
\text { and Klaipèda }\end{array}$ & 961 & 100 & 74 & 7,7 & 50 & 5,2 & 837 & 87,1 \\
\hline Total & 14553 & 100 & 552 & 3,8 & 2170 & 14,9 & 11831 & 81,3 \\
\hline
\end{tabular}

However, it is difficult to win back "the lost" passengers.

Another important fact in favour of a car is a possibility of travelling without changing means, i.e. from "door to door" which shortens the duration of a travel as compared with public transport. In the latter case a certain amount of time is wasted on getting to a railway or bus station and then from here to the final point of destination. All these factors determine the priority of a car in public transport.

Therefore the main task of intercity public railway and road transport is not only to compete with each other but mostly to collaborate and, thus, "win the passengers back from cars".

\section{The Establishment of the Prospective Railway and Road Markets}

The author's carried out research has proved that in the process of increasing the communication speed and extending the passenger service on a train, the prospec- tive market of transportation would assume the following shape (Fig 2):

1. The routes for internal intercity transportation would be as follows: Vilnius - Šiauliai - Klaipèda; Vilnius - Kaunas; Vilnius - Turmantas; Vilnius - Varena; Kaunas - Šiauliai - Klaipèda; Kaunas - Kybartai; Šiauliai Mažeikiai.

2. The routes for internal local transportation would be: Vilnius - Stasylos, Vilnius - Lentvaris, Vilnius Kena, Vilnius - Trakai, Radviliškis - Šiauliai, Klaipėda - Kretinga, Klaipeda - Šilutè - Pagėgiai.

The main flows of passengers travelling along the above - listed routes should be transported by rail.

3. Railway transport has to collaborate with road transport on the routes: Vilnius - Kretinga - (Palanga) Klaipeda and Vilnius - Marcinkonys - (Druskininkai), i.e. changing from a railway transport means to a road one in Kretinga, passengers have to be further transported to Palanga (and from here to Kretinga), and passengers who are delvered to Marcinkonys by rail have to be fur- 


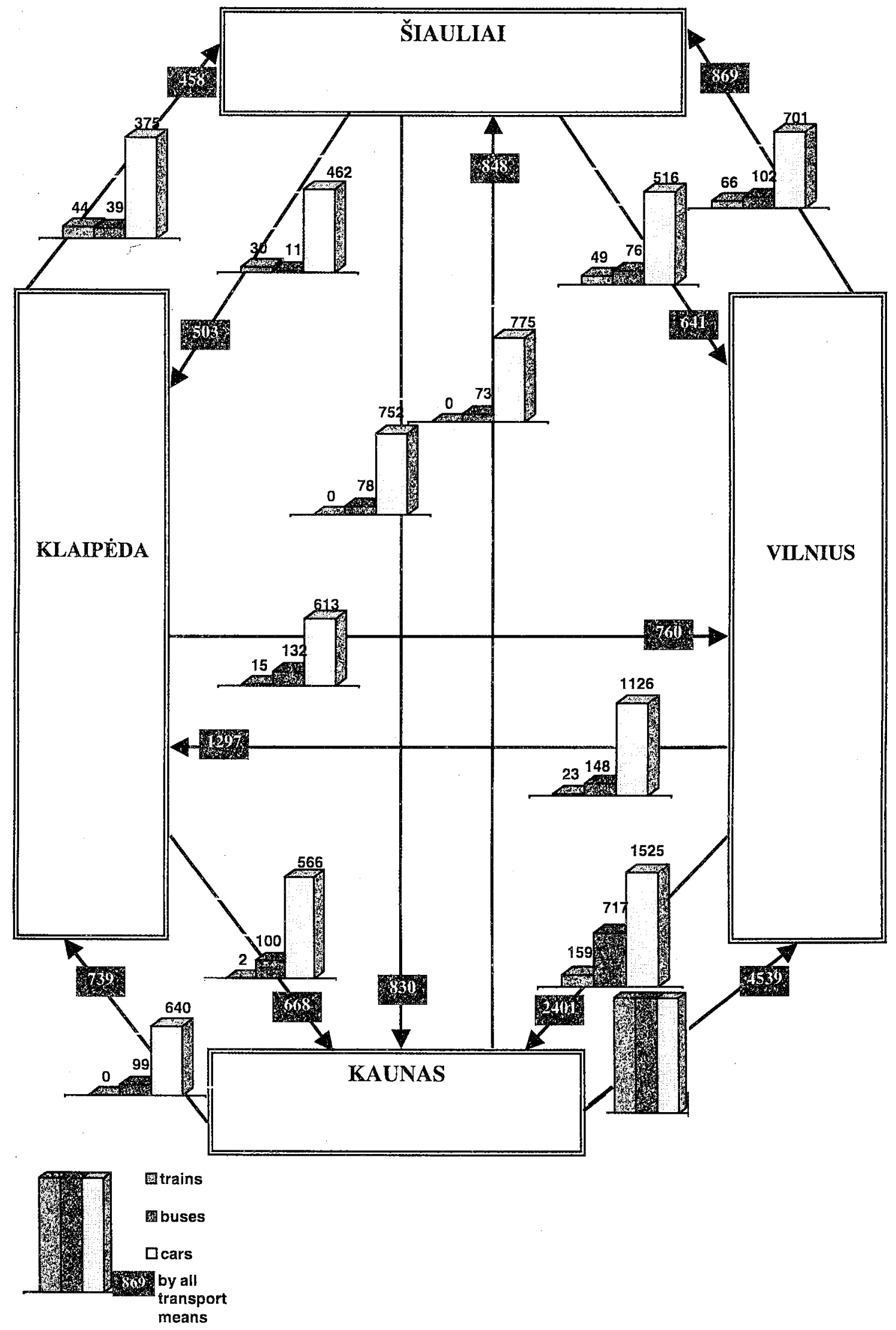

Fig 1. The flows of passengers going by train, bus or car among Vilnius, Kaunas, Šiauliai and Klaipeda (directly from one city to another one), passengers/day 


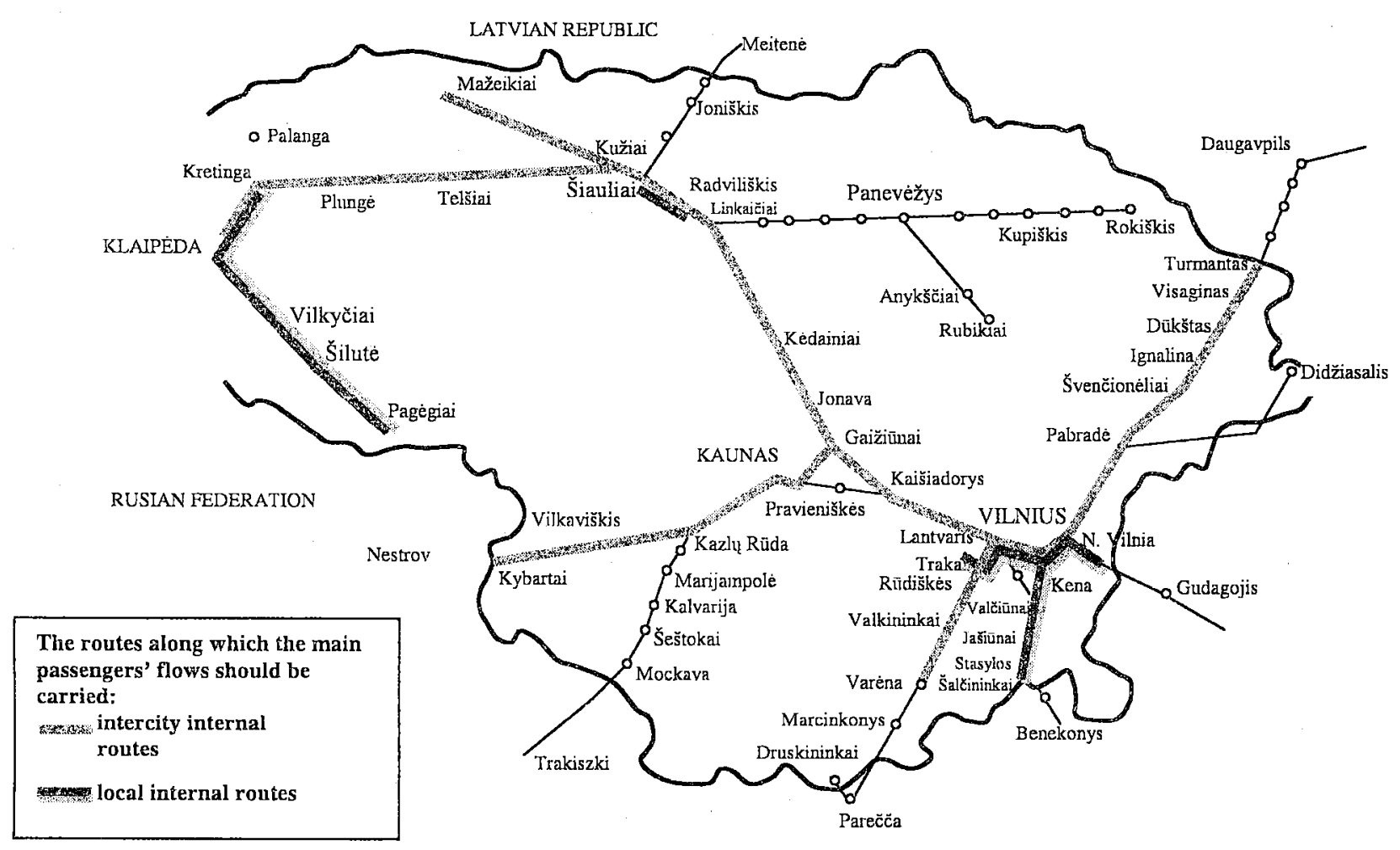

Fig 2. The prospective market of transportations by railway

ther transported to Druskininkai by road (and from here back to Marcinkonys).

4. The main flows of passengers travelling along such routes as Vilnius - Kaunas, Kaunas - Klaipeda, Vilnius - Varéna, Vilnius - Turmantas should be transported by rail whereas the internal road transport should convey them within the region as well as transport them close to the railway lines.

5. Railway transport will compete with road transport on such routes as Kaunas - Jonava, Šiauliai Rokiškis, Kaunas - Marijampolè - Šeštokai.

6. Passengers will be conveyed by road along other internal distant and local communication routes.

7. Having introduced the above - high speed railway line, the international market of passenger transportations will also be redistributed. Having applied the formalized models, it has been ascertained that the construction of the above-mentioned high speed railway line would rearrange the transportation market as follows:

- high speed railways would take over from $15 \%$ up to $60 \%$ of passengers from individual car transport;

- high speed railways would take over from $12 \%$ up to $80 \%$ of passengers from air transport;

- high speed railways would take from $40 \%$ up to $90 \%$ of passengers from road transport (buses).

\section{Conclusions}

1. The main way for the Lithuanian railway integration into the European network of high speed railways, is the construction of the European track for the high speed railway line in Kreta I corridor.

2. The high speed railway line would extend from Berlin via Warsaw up to Tallinn with a branch to St. Petersburg.

3. It is expedient to design a mixed high speed railway line, intended for both passenger and goods traffic.

4. The research carried out by the author, has demonstrated that cars dominate in passenger transportations among Lithuania's four major cities: Vilnius, Kaunas, Klaipeda and Šiauliai, which transport $81,3 \%$ of direct passengers. Buses (including microbuses) transport only $14,9 \%$ of passengers and trains carry only $3,8 \%$ of passengers. Thus, the main problem of intercity public transport is to win the passengers back from automobiles.

5. The occupancy of a car in intercity transportations is only $1,5 \div 1,8$ passengers (including the driver). This determines a higher cost of a car journey, rather than that by train or bus.

6. In the presented work prospective railway and road markets for local, intercity and international transportation have been identified. 


\section{References}

1. Brännlung, U.; Lindberg, P. O.; Nou, A.; Nillson, J.-E. Railway Time-tabling Using Lagrangian Relaxation. Transpor tation Science, Vol 32, 1998, p. 358-369.

2. European Rail Traffic Management System. European Comission Directorate - General Transport, Luxemburg: Publiching of the European Communities, 1996. 127 p.

3. High-Level Group. The European High - speed Train Network. February 1995, Luxemburg: Office for Official Publications of the European Communitics, 1995. BrusselsLuxemburg, 1995. $168 \mathrm{p}$.

4. Knutton, M. Time for a re-think of high-speed rail priorities. International Railway Journal, No 7. Cornwall, 1999, p. $14-17$

5. The second stage railway reform of Germany. Railways of the World (Железные дороги мира), № 6, 1999, p. 5-10 (in Russian).
6. Kiseliov, I. P.; Sotnikov, E. A.; Suchodojev, V. S. The high speed railways (Высокоскоростные железные дороги). St. Petersburg, 2001. 60 p. (in Russian).

7. Sakalauskas, K.; Rezgaitis, R. Problems and perspectives of traffic of hight speed passenger trains. Transport Engineering (Transportas), Vol XV, No 5. Vilnius: Technika, 2000 , p. 244256 (in Lithuanian)

8. Butkevičius, J. The perspectives of establishment of hight speed railways in Lithuania. In: Transbaltica'01. (Tarptautinès konferencijos moksliniu pranešimu rinkinys). Vilnius: Technika, 2001, p. 109-113 (in Lithuanian).

9. Butkevičius, J.; Baublys, A. The development of freight and passenger transportation by railway across the Lithuanian/ Polish border. In: Humanisation in technology (Technikos humanizavimas). Vilnius: Technika, 2001, p. 31-35.

10. Butkevičius, J. The passenger transportation. The monograph (Keleivių vežimai. Monografija). Vilnius: 2002. 416 p. (in Lithuanian). 